\title{
PELATIHAN PENGEMBANGAN INSTRUMEN PENILAIAN NUMERASI UNTUK PENINGKATAN KOMPETENSI GURU MATEMATIKA SMP
}

\author{
Meiliasari, Wardani Rahayu, Ratna Maryam \\ Universitas Negeri Jakarta \\ Email: meiliasari@unj.ac.id, wardani.rahayu@unj.ac.id, maryamratna@gmail.com
}

\begin{abstract}
Asesmen Kompetensi Minimum (AKM) or Minimum Competency Assessment has different objectives and formats compared to Ujian Nasional (National Exam), therefore teachers need to upgrade their knowledge of assessment instruments that measure students' numeracy skills. This training aims to develop teachers' professionalism and competence in developing numeracy assessment instruments. The training was carried out online through a Zoom Meeting with participants of 29 junior high school mathematics teachers in Bogor Regency, West Java. The training was delivered in 2 sessions by 2 mathematics education lecturers from Universitas Negeri Jakarta. The first session with topics of AKM discussed the material domain, cognitive level, and the form of the questions on the AKM questions. The second session was with topics of numeracy skills discussed the benefits and the definition of numeracy skills. At the end of the training, participants were assigned to make a numeracy assessment instrument within 1 week. Participants and presenters join WhatsApp groups as a forum for discussion in the process of doing assignments. This training activity produces an output in the form of a numeracy assessment instrument that is developed based on the AKM question format. Participants are motivated and have ideas to develop numeracy assessment instruments.
\end{abstract}

Keywords: Asesmen Kompetensi Minimum; Numeracy Assessment Instrument; Mathematics; teachers' professional development

\begin{abstract}
Abstrak
Asesmen Kompetensi Minimum (AKM) memiliki tujuan dan format yang berbeda dari Ujian Nasional, sehingga guru perlu menyiapkan penilaian kelas yang mampu mengukur kemampuan numerasi siswa. Pelatihan ini bertujuan untuk mengembangkan profesionalisme dan kompetensi guru dalam membuat instrumen penilaian numerasi. Pelatihan dilaksanakan secara online melalui Zoom Meeting dengan peserta 29 guru matematika SMP di Kabupaten Bogor, Jawa Barat. Pelatihan diberikan dalam 2 sesi oleh 2 dosen Program Studi Pendidikan Matematika UNJ. Sesi pertama dengan materi mengenai AKM membahas mengenai domain materi, tingkat kognitif, dan bentuk soal pada soal AKM. Sesi kedua dengan materi kemampuan numerasi numerasi membahas mengenai manfaat dan pengertian kemampuan numerasi. Pada akhir pelatihan peserta ditugaskan untuk membuat instrumen penilaian numerasi dalam waktu 1 minggu. Peserta dan pemateri bergabung dalam grup WhatsApp sebagai wadah diskusi dalam proses mengerjakan tugas. Kegiatan pelatihan ini menghasilkan luaran berupa instrumen penilaian numerasi yang disusun berdasarkan format soal AKM. Peserta termotivasi dan memiliki ide untuk menyusun instrumen penilaian numerasi.
\end{abstract}

Kata Kunci: Asesemen Kompetensi Minimum; Instrumen Penilaian Numerasi; Matematika; Pengembangan profesionalisme guru 


\section{PENDAHULUAN}

Kementerian Pendidikan,

Kebudayaan, Riset dan Teknologi Republik Indonesia telah mulai memberlakukan Asesmen Kompetensi Minimum (AKM) untuk tingkat SD, SMP, dan SMA. AKM menilai kompetensi minimum yang diperlukan oleh siswa untuk mampu berpartisipasi positif dan berkompetisi dalam masyarakat global. AKM mengukur kemampuan literasi membaca dan literasi matematika (atau biasa disebut numerasi). Keduanya mengedepankan keterampilan berpikir logis-sistematis, keterampilan bernalar, serta keterampilan memilah dan mengolah informasi (Kemendikbud, 2021). Kemampuan tersebut termasuk dalam kemampuan berpikir tingkat tinggi yang dapat diukur melalui soal-soal non rutin.

Selayaknya kebijakan baru, AKM masih menyisakan banyak pertanyaan bagi guru. Pada umumnya guru terbiasa memberikan soal rutin yang dapat diselesaikan secara langsung dengan menggunakan rumus (Kartikasari, Kusmayadi, \& Usodo, 2016). Pergeseran dari penggunaan soal rutin menjadi soal non rutin haruslah diikuti dengan kesiapan guru dalam mengembangkan instrumen penilaian terkait. Namun, guru mengalami kesulitan dalam merancang dan menerapkan soal-soal berbasis HOTS (Damianus D. Samo, 2017; Subroto Rapih \& Sutaryadi, 2018).

Tidak terkecuali para guru matematika SMP di Kabupaten Bogor, Jawa Barat. Kabupaten Bogor berbatasan dengan banyak kota lain sehingga menjadi salah satu tujuan utama untuk bermukim dan menjadikan Bogor sebagai kota dengan populasi penduduk terbesar di Provinsi Jawa Barat. Hal ini memicu berbagai permasalahan yang kompleks, salah satunya di bidang pendidikan.

Terdapat 726 SMP dengan total 216.638 siswa dan 8.945 guru (Dapodik, 2021). Oleh karena itu, pemerintah Kabupaten Bogor memiliki tugas yang sangat berat dalam meningkatkan penyediaan layanan pendidikan yang berkualitas. Sebagaimana kita ketahui, kualitas pendidikan menjadi salah satu faktor keberhasilan suatu negara untuk dapat berkompetisi secara global.

Salah satu upaya yang dapat dilakukan untuk meningkatkan kualitas pendidikan adalah dengan meningkatkan kualitas guru. Memperbaiki kualitas guru merupakan bagian dari peningkatan profesionalitas guru yang dapat dilakukan salah satunya melalui pelatihan. Pelatihan yang diberikan hendaknya dapat terintegrasi dengan pembelajaran sehingga dapat lebih efektif (Stigler \& Hiebert, 2010). Selain itu, agar pelatihan menjadi efektif, hendaknya juga memerhatikan beberapa hal, di antaranya: (1) fokus pada suatu topik, (2) menerapkan pembelajaran aktif, dan (3) diberikan oleh para ahli (Darling-Hammond et al., 2017).

Berdasarkan penjabaran tersebut, maka diadakan kegiatan pelatihan pembuatan instrumen penilaian kemampuan numerasi untuk guru matematika SMP di Kabupaten Bogor, Jawa Barat. Melalui kegiatan pelatihan ini, guru matematika SMP di Kabupaten Bogor diharapkan dapat 
mengembangkan instrumen penilaian numerasi yang sesuai dengan format soal AKM.

\section{TINJAUAN LITERATUR}

Pemberlakuan AKM menegaskan bahwa perhatian pemerintah akan pembangunan kualitas sumber daya manusia khususnya keterampilan literasi siswa. AKM mengukur kemampuan literasi membaca dan literasi numerasi siswa (Novita, Mellyzar, \& Herizal, 2021).

Numerasi merupakan kemampuan yang dibutuhkan oleh seseorang untuk dapat berfungsi dan berkontribusi dengan baik dalam masyarakat (OECD \& Statistics Canada, 2000). Kemampuan numerasi juga merupakan salah satu faktor penentu keberhasilan seseorang di pekerjaannya (Tyler, Murnane, \& Willett, 2000; Green \& Riddell, 2001).

Kesadaran akan pentingnya kemampuan numerasi menjadi penggerak reformasi dalam pembelajaran matematika. Untuk menumbuhkan kemampuan numerasi, beberapa strategi yang dapat dilakukan. Misalnya dengan mengintegrasikan teknologi dalam pembelajaran matematika (Miller, 2018), dan mengunakan permainan matematika (Cohrssen \& Niklas, 2019).

Selain itu, aspek pembelajaran yang juga penting adalah penilaian numerasi. Untuk mengukur kemampuan numerasi siswa diperlukan soal-soal non-rutin. Dalam penilaian numerasi, soal yang diberikan perlu dapat menunjukkan aplikasi matematika dalam berbagai konteks kehidupan. OECD
(2019) menetapkan konteks personal, pekerjaan, social, dan sains dalam soalsoal PISA. Selain itu OECD (2019) juga perlu menargetkan proses matematika berupa penalaran matematika dan pemecahan masalah dalam soal-soal PISA.

\section{METODE PELAKSANAAN}

Kegiatan pelatihan ini diikuti oleh guru matematika SMP di Kabupaten Bogor, Jawa Barat. Pelatihan dilakukan secara daring melalui Zoom Meeting pada. Narasumber pada pelatihan ini adalah dua dosen program studi pendidikan matematika.

Pelaksanaaan kegiatan ini menggunakan beberapa metode pelatihan, yaitu:

1. Metode Ceramah. Peserta guru akan diperkenalkan tentang AKM dan numerasi.

2. Metode Tanya Jawab. Peserta guru diberikan kesempatan untuk bertanya. Seluruh perserta berkesempatan untuk berdialog dengan narasumber.

3. Metode Kerja Kelompok. Peserta guru melakukan diskusi dan kerja kelompok dalam menyusun penilaian dan soal-soal numerasi.

4. Pada akhir sesi materi, para peserta ditugaskan untuk mengembangkan instrumen penilaian numerasi dalam waktu 1 minggu.

\section{HASIL DAN PEMBAHASAN}

Kegiatan pelatihan dilakukan secara daring pada hari Rabu, 29 September 2021. Pelatihan dilaksanakan secara daring melalui Zoom Meeting. 
Peserta terdiri dari 29 guru matematika SMP di Kabupaten Bogor, Jawa Barat. Kegiatan dimulai dengan pengisian presurvey untuk mengetahui pengetahuan awal peserta mengenai AKM dan penilaian numerasi. Pre-survey diberikan secara daring.

Melalui pre-survey diketahui bahwa beberapa peserta guru belum pernah mengikuti kegiatan pelatihan penulisan soal numerasi. Tabel 1 menampilkan beberapa jawaban peserta guru mengenai pelatihan yang pernah diikuti sebelumnya. Pelatihan yang banyak diikuti guru adalah pelatihan yang berkaitan dengan keterampilan teknologi informasi mengenai pengembangan media pembelajaran dan sistem pembelajaran elektronik di sekolah. Kemampuan guru dalam mengintegrasikan teknologi dengan pembelajaran dapat diterapkan dalam strategi meningkatkan kemampuan numerasi (Miller, 2018).

Tabel 1. Pelatihan yang pernah diikuti peserta

\section{Sebutkan pelatihan apa saja yang pernah diikuti}

\begin{tabular}{ll}
\hline 1. & Pelatihan penyusunan soal AKM bersama MGMP \\
\hline 2. & Pelatihan Master Trainer HOTS, Pelatihan pola berpikir aljabar \\
\hline 3. & Pembelajaran berbasis IT \\
\hline 4. & Pelatihan menggunakan aplikasi LMS \\
\hline 5. & Pelatihan AKM dari MGMP \\
\hline 6. & Canva, Geogebra, Media Pembelajaran Jarak Jauh \\
\hline 7. & Desmos, Geogebra, PMRI, FX Math Pack \\
\hline 8. & Mendeley, Geogebra, FX, SPSS, stop motion, dll. \\
\hline 9. & Pelatihan LMS \\
\hline 10. & Canva, Office 365
\end{tabular}

Hasil pre-survey juga menunjukkan pendapat para peserta guru dalam beberapa hal. Pada Tabel 2 butir nomor $1-4$ adalah perihal pengetahuan awal peserta guru mengenai kemampuan numerasi. Sedangkan butir nomor $5-7$ perihal pelaksanaan pelatihan. Bobot $(d)$ setiap pernyataan adalah 5 untuk sangat setuju, berurutan hingga 1 untuk sangat tidak setuju. Responden pada pre-survey adalah sebanyak 24 responden $(n)$.

Terlihat pada butir pernyataan nomor 1 bahwa guru merasa belum memiliki pengetahuan yang cukup mengenai kemampuan numerasi. Lebih lanjut, butir nomor 4 menunjukkan bahwa guru merasa perlu adanya pembaharuan dalam metode mengajar. Guru juga merasa perlunya mengikuti pelatihan sebagai penunjang profesi, salah satunya dengan mendapatkan informasi lebih mengenai referensi dalam pengembangan bahan ajar. Guru menginginkan pelatihan yang disampaikan dengan teknik yang menarik dan dapat memberikan kesempatan peserta untuk aktif, guru juga meyakini metode pelatihan daring dapat mengakomodasi hal tersebut. 
Tabel 2. Respon Peserta Guru pada Pre Survey

\begin{tabular}{|c|c|c|c|c|c|c|c|}
\hline No. & Perihal & $\begin{array}{l}\text { Sangat } \\
\text { Setuju }\end{array}$ & Setuju & $\begin{array}{c}\text { Ragu- } \\
\text { ragu }\end{array}$ & $\begin{array}{l}\text { Tidak } \\
\text { Setuju }\end{array}$ & $\begin{array}{l}\text { Sangat } \\
\text { Tidak } \\
\text { Setuju }\end{array}$ & $\frac{\sum f \cdot d}{n}$ \\
\hline 1. & $\begin{array}{l}\text { Pengetahuan awal } \\
\text { mengenai kemampuan } \\
\text { numerasi. }\end{array}$ & 2 & 6 & 6 & 7 & 3 & 2,88 \\
\hline 2. & $\begin{array}{l}\text { Pelatihan sebagai } \\
\text { penunjang profesi. }\end{array}$ & 2 & 6 & 10 & 5 & 1 & 3,13 \\
\hline 3. & $\begin{array}{l}\text { Referensi dalam } \\
\text { menyusun dan } \\
\text { mengembangkan } \\
\text { bahan ajar. }\end{array}$ & 1 & 5 & 12 & 5 & 1 & 3,00 \\
\hline 4. & $\begin{array}{l}\text { Pembaharuan metode } \\
\text { mengajar tidak } \\
\text { diperlukan. }\end{array}$ & 0 & 2 & 6 & 11 & 5 & 2,21 \\
\hline 5. & $\begin{array}{l}\text { Pelatihan secara } \\
\text { daring memberikan } \\
\text { hasil yang optimal. }\end{array}$ & 3 & 12 & 8 & 1 & 0 & 3,71 \\
\hline 6. & $\begin{array}{l}\text { Pelatihan secara } \\
\text { daring memberi } \\
\text { kesempatan peserta } \\
\text { untuk aktif. }\end{array}$ & 3 & 12 & 7 & 2 & 0 & 3,67 \\
\hline 7. & $\begin{array}{l}\text { Pelatihan perlu } \\
\text { disampaikan dengan } \\
\text { teknik yang menarik. }\end{array}$ & 6 & 18 & 0 & 0 & 0 & 4,25 \\
\hline & Persentase & 10,12 & 36,31 & 29,17 & 18,45 & 5,95 & 100 \\
\hline
\end{tabular}

Pelatihan dibagi menjadi dua sesi. Sesi pertama dengan materi mengenai AKM membahas domain materi, tingkat kognitif, dan bentuk soal pada soal AKM. Domain materi pada AKM terdiri dari domain Bilangan, Geometri dan Pengukuran, Aljabar, dan Data dan Ketidakpastian. Domain materi tersebut sama dengan lingkup materi pada UN untuk tingkat SMP. Hal yang membedakan adalah kompetensi yang diuji dari setiap domain materi seperti ditunjukkan pada Gambar 1. Pada AKM, kompetensi dibuat menjadi lebih sedikit namun mendalam sehingga membutuhkan keterampilan berpikir logis-sistematis, keterampilan bernalar, serta keterampilan memilah dan mengolah informasi dalam penyelesaian soal (Kemendikbud, 2021).

Soal-soal AKM dan UN samasama dihadirkan dalam 3 tingkat kognitif, yaitu pemahaman, penerapan, dan penalaran. Perbedaannya adalah soal-soal AKM tidak hanya disajikan dalam bentuk soal pilihan ganda, namun 
juga dalam bentuk pilihan ganda dengan benar-salah atau semacamnya, jawaban lebih dari satu, pilihan ganda menjodohkan, isian singkat, serta uraian.

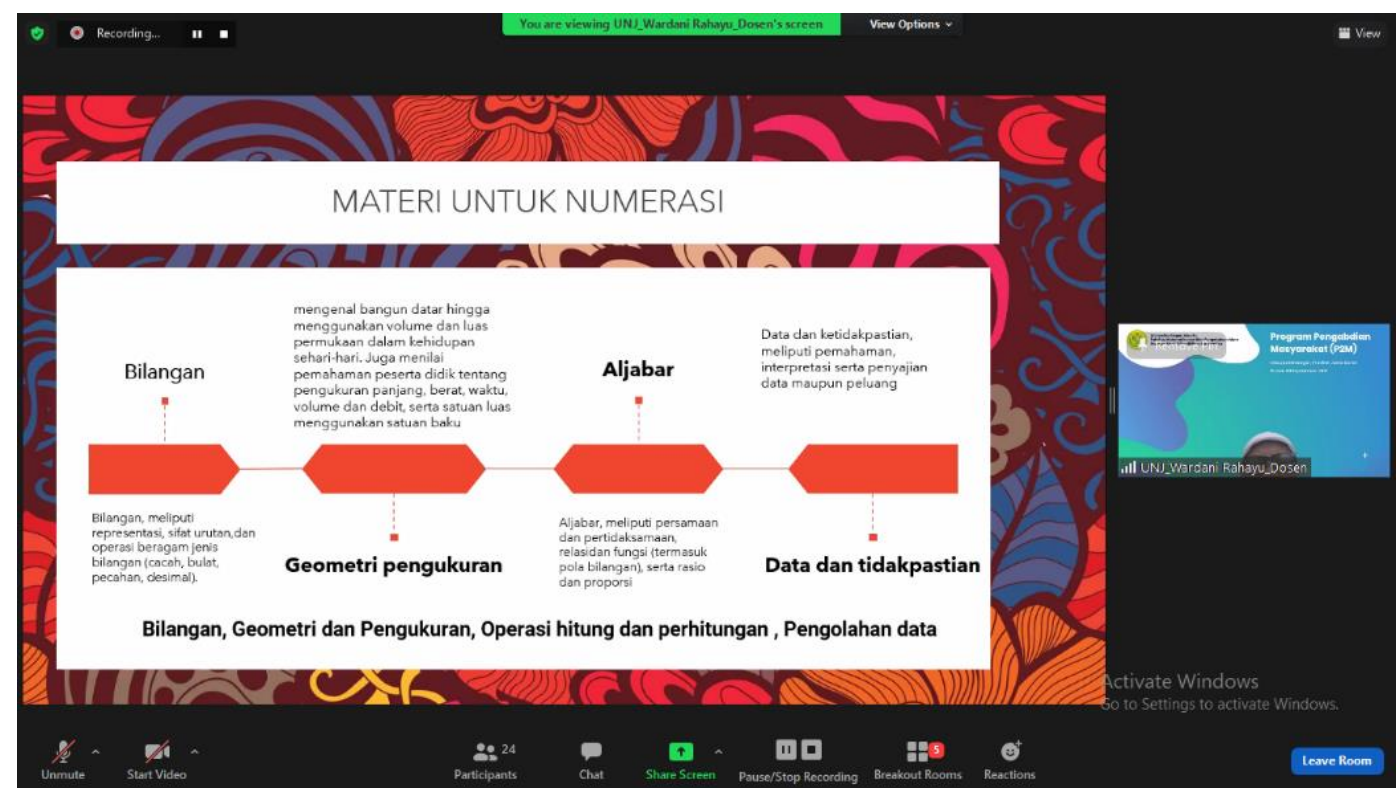

Gambar 1. Domain Materi Soal AKM

Sesi kedua dengan materi kemampuan numerasi membahas mengenai manfaat dan pengertian kemampuan numerasi. Dalam pelatihan ini peserta diminta mengeksplorasi mencoba mengerjakannya dan saling mendiskusikan berbagai strategi untuk pemecahan soal tersebut. Gambar 2 menunjukkan contoh soal yang dieksplorasi bersama oleh peserta. beberapa contoh soal numerasi dengan

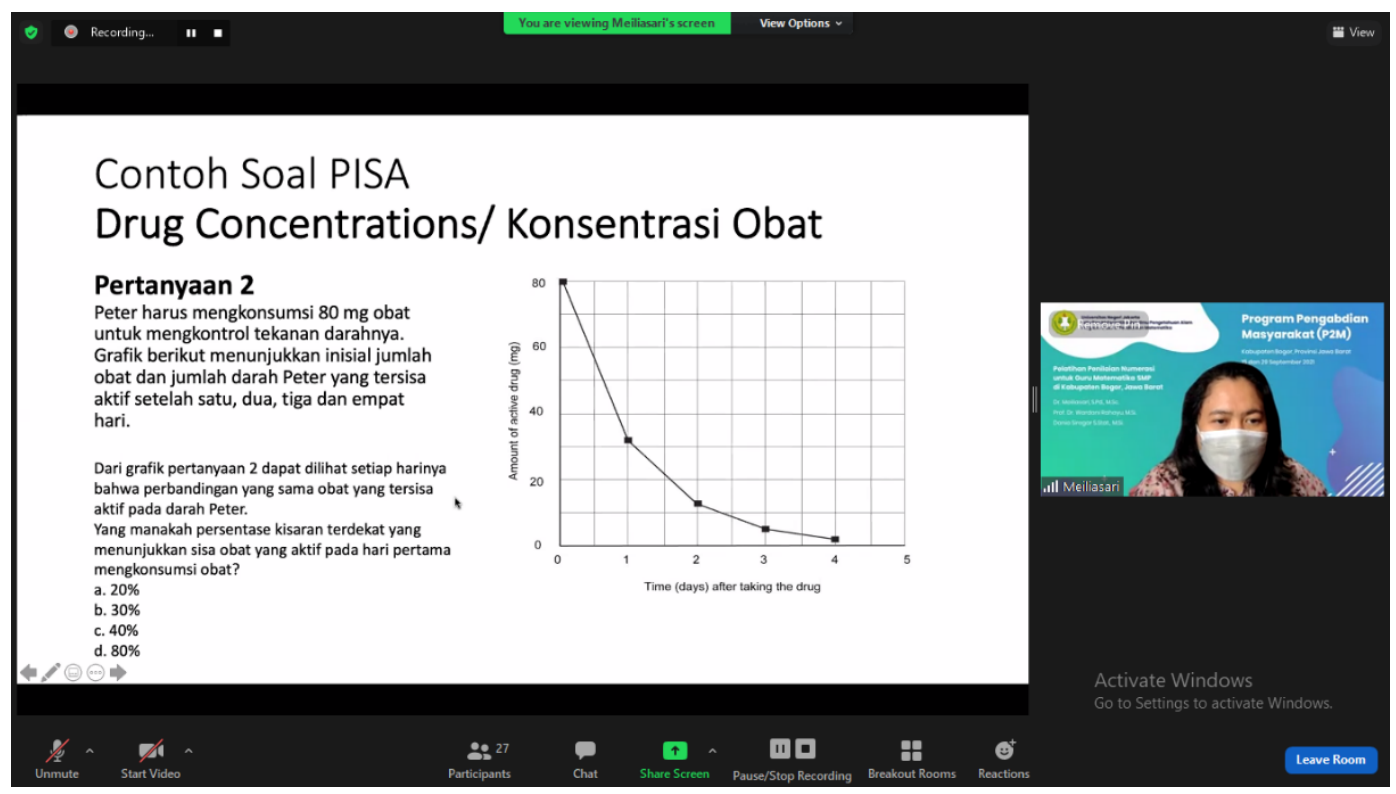

Gambar 2. Peserta mengeksplorasi contoh soal 
Beberapa peserta guru dapat menjawab dengan benar, sementara beberapa yang lain memerlukan waktu lebih untuk memahami wacana yang diberikan. Setiap soal terdiri atas wacana mengenai suatu konteks personal, sosial budaya, atau saintifik. Peserta didik perlu menganalisis setiap wacana agar dapat menyelesaikan soal.

Pada akhir kegiatan, peserta juga diminta untuk mengisi post-survey berkaitan dengan pengetahuan peserta mengenai kemampuan numerasi setelah mengikuti pelatihan serta pelaksanaan pelatihan itu sendiri. Tabel 3 menunjukkan respon peserta dari postsurvey. Terlihat bahwa materi yang disampaikan oleh para narasumber sudah sangat jelas dan mudah dipahami serta sudah sesuai dengan kompetensi yang dibutuhkan para guru. Apabila dibandingkan, hasil respon peserta dalam pre-survey dan post-survey terlihat bahwa pelatihan yang diberikan dapat meningkatkan kemampuan berpikir kritis guru, memberikan ide pengembangan bahan ajar, dan juga memotivasi para guru untuk terus mempelajari lebih lanjut mengenai kemampuan numerasi.

Pada akhir pelatihan peserta ditugaskan untuk membuat instrumen penilaian numerasi dalam waktu 1 minggu. Pengumpulan tugas dilakukan dengan menggunkan Google Form. Para peserta guru dan kedua narasumber tergabung dalam grup WhatsApp di mana antar peserta dan narasumber dapat berdiskusi mengenai tugas pembuatan instrumen numerasi yang diberikan.

Gambar 3 merupakan soal numerasi yang dibuat oleh salah satu peserta, Guru IS. Soal ini menunjukkan pemahaman Guru IS mengenai pemilihan wacana atau konteks yang digunakan. Guru IS menggunakan data Jumlah dan Persentase Penduduk Miskin di Suatu Daerah yang diambil dari situs resmi milik pemerintah (Badan Pusat Statistik).

Guru IS dapat membuat 3 buah soal dari 1 konteks yang sama. Ketiga soal yang dibuat tersebut berturut-turut berada pada tingkat kognitif pemahaman, penerapan, dan penalaran. 2 soal dibuat dalam bentuk pilihan ganda dan 1 soal dibuat dalam bentuk pilihan ganda kompleks lebih dari 1 jawaban. Soal pada Gambar 3 merupakan soal dengan tingkat kognitif penalaran. Hal ini menunjukkan kemampuan peserta guru dalam merancang soal numerasi sendiri. Guru mampu memanfaatkan teknologi untuk mencari informaasi berupa data asli, dengan menggunakan data asli peserta didik diharapkan dapat lebih memahami fungsi dan tujuan pembelajara terkait. Guru IS juga mampu menyesuaikan tingkat kognitif yang hendak dinilai dengan bentuk soal. Bentuk soal pilihan ganda kompleks dengan jawaban lebih dari satu memerlukan analisis peserta didik pada setiap pilihan jawaban yang tersedia. 
Tabel 3. Respon Peserta Guru pada Post Survey

\begin{tabular}{|c|c|c|c|c|c|c|c|}
\hline No. & Perihal & $\begin{array}{l}\text { Sangat } \\
\text { Setuju }\end{array}$ & Setuju & $\begin{array}{l}\text { Ragu- } \\
\text { ragu }\end{array}$ & $\begin{array}{l}\text { Tidak } \\
\text { Setuju }\end{array}$ & $\begin{array}{c}\text { Sangat } \\
\text { Tidak } \\
\text { Setuju }\end{array}$ & $\begin{array}{l}\text { Bobot } \\
\frac{\sum f \cdot d}{n}\end{array}$ \\
\hline 1. & $\begin{array}{l}\text { Sistematika materi yang } \\
\text { diberikan. }\end{array}$ & 14 & 12 & 1 & 0 & 0 & 4,481 \\
\hline 2. & $\begin{array}{l}\text { Kejelasan materi yang } \\
\text { diberikan. }\end{array}$ & 13 & 13 & 1 & 0 & 0 & 4,44 \\
\hline 3. & $\begin{array}{l}\text { Kesesuaian materi } \\
\text { dengan kompetensi yang } \\
\text { dibutuhkan. }\end{array}$ & 14 & 12 & 1 & 0 & 0 & 4,48 \\
\hline 4. & $\begin{array}{l}\text { Kebermanfaatan materi } \\
\text { yang diberikan. }\end{array}$ & 17 & 10 & 0 & 0 & 0 & 4,63 \\
\hline 5. & $\begin{array}{l}\text { Pengetahuan } \\
\text { narasumber. }\end{array}$ & 17 & 9 & 1 & 0 & 0 & 4,59 \\
\hline 6. & $\begin{array}{l}\text { Penyampaian materi } \\
\text { secara jelas. }\end{array}$ & 15 & 11 & 1 & 0 & 0 & 4,52 \\
\hline 7. & $\begin{array}{l}\text { Pengembangan } \\
\text { kemampuan berpikir } \\
\text { kritis peserta. }\end{array}$ & 15 & 11 & 1 & 0 & 0 & 4,52 \\
\hline 8. & $\begin{array}{l}\text { Komunikasi terjalin } \\
\text { dengan baik. }\end{array}$ & 13 & 13 & 1 & 0 & 0 & 4,44 \\
\hline 9. & $\begin{array}{l}\text { Suasana pelatihan } \\
\text { menyenangkan. }\end{array}$ & 12 & 13 & 2 & 0 & 0 & 4,37 \\
\hline 10. & $\begin{array}{l}\text { Jawaban narasumber } \\
\text { mudah dimengerti. }\end{array}$ & 14 & 12 & 1 & 0 & 0 & 4,48 \\
\hline 11. & $\begin{array}{l}\text { Intonasi suara } \\
\text { narasumber jelas. }\end{array}$ & 14 & 12 & 1 & 0 & 0 & 4,48 \\
\hline 12. & Peserta berperan aktif. & 11 & 14 & 2 & 0 & 0 & 4,33 \\
\hline 13. & $\begin{array}{l}\text { Materi tersampaikan } \\
\text { dengan optimal. }\end{array}$ & 9 & 16 & 2 & 0 & 0 & 4,26 \\
\hline 14. & $\begin{array}{l}\text { Pengetahuan baru setelah } \\
\text { pelatihan. }\end{array}$ & 12 & 13 & 2 & 0 & 0 & 4,37 \\
\hline 15. & $\begin{array}{l}\text { Materi yang disampaikan } \\
\text { dapat dipahami. }\end{array}$ & 10 & 16 & 1 & 0 & 0 & 4,33 \\
\hline 16. & $\begin{array}{l}\text { Motivasi untuk } \\
\text { mempelajari lebih lajut } \\
\text { mengenai numerasi. }\end{array}$ & 16 & 11 & 0 & 0 & 0 & 4,593 \\
\hline \multirow[t]{2}{*}{17.} & $\begin{array}{l}\text { Ide untuk pengembangan } \\
\text { bahan ajar. }\end{array}$ & 13 & 14 & 0 & 0 & 0 & 4,48 \\
\hline & Persentase & 49,9 & 46,2 & 3,90 & 0 & 0 & 100 \\
\hline
\end{tabular}




\begin{tabular}{|c|c|c|}
\hline \multicolumn{3}{|c|}{$\begin{array}{l}\text { Jumlah dan Persentase Penduduk Miskin Menurut Daerah } \\
\text { September 2019-September } 2020\end{array}$} \\
\hline Daerah/Tahun & Jumlah Penduduk Miskin (juta orang) & Persentase Penduduk Miskin \\
\hline (1) & (2) & (3) \\
\hline \multicolumn{3}{|l|}{ Perkotaan } \\
\hline September 2019 & 9,86 & 6,56 \\
\hline Maret 2020 & 11,16 & 7,38 \\
\hline September 2020 & 12,04 & 7,88 \\
\hline \multicolumn{3}{|l|}{ Perdesaan } \\
\hline September 2019 & 14,93 & 12,60 \\
\hline Maret 2020 & 15,26 & 12,82 \\
\hline September 2020 & 15,51 & 13,20 \\
\hline \multicolumn{3}{|l|}{ Total } \\
\hline September 2019 & 24,79 & 9,22 \\
\hline Maret 2020 & 26,42 & 9,78 \\
\hline September 2020 & 27,55 & 10,19 \\
\hline \multicolumn{3}{|c|}{$\begin{array}{l}\text { Sumber: Diolah dari data Survei Sosial Ekonomi Nasional (Susenas) September 2019, Maret 2020, dan September } 202 \\
\text { Perhatikan tabel yang disajikan di atas mengenai jumlah dan persentase penduduk } \\
\text { miskin menurut daerah (periode September 2019, Maret } 2020 \text { dan September 2020) } \\
\text { yang dikutip dari Badan Pusat Statistik (www.bps.go.id). }\end{array}$} \\
\hline \multicolumn{3}{|c|}{ Pernyataan yang benar sesuai tabel di atas adalah... } \\
\hline \multicolumn{3}{|c|}{ Presentase penduduk miskin bulan Maret 2020 sebesar 9,78 \% } \\
\hline \multicolumn{3}{|c|}{$\begin{array}{l}\text { Selisih penduduk miskin di perkotaan dan pedesaan pada bulan September } 2020 \\
\text { sebesar 3,4 juta }\end{array}$} \\
\hline \multicolumn{3}{|c|}{ Rata-rata penduduk miskin di perdesaan lebih besar dari perkotaan } \\
\hline \multicolumn{3}{|c|}{ Persentase penduduk miskin di perkotaan lebih dari $9 \%$} \\
\hline \multicolumn{3}{|c|}{ Persentase penduduk miskin tiap tahun bertambah } \\
\hline
\end{tabular}

Gambar 3. Contoh Soal Buatan Peserta Guru

(Konteks Sosial Budaya pada Domain Data dan Ketidakpastian)

\section{PENUTUP}

Penutup berisi kesimpulan dan saran. Kesimpulan menggambarkan jawaban dari hipotesis dan/atau tujuan penelitian atau temuan yang diperoleh. Kesimpulan bukan berisi perulangan dari hasil dan pembahasan, tetapi lebih kepada ringkasan hasil temuan seperti yang diharapkan di tujuan atau hipotesis. Saran menyajikan hal-hal yang akan dilakukan terkait dengan gagasan selanjutnya dari pengabdian Masyarakat tersebut.

Berdasarkan hasil dan pembahasan mengenai respon peserta pada survey sebelum dan sesudah pelatihan, dapat 
disimpulkan bahwa pelatihan yang telah dilaksanakan membantu para guru untuk dapat lebih mengenal soal-soal numerasi yang disajikan pada AKM. Para guru juga dapat lebih memahami manfaat dan tujuan penilaian numerasi, ciri-ciri soal numerasi, ide untuk mengembangkan soal numerasi, serta referensi mengenai soal numerasi.

Berdasarkan tugas yang terkumpul, dapat disimpulkan bahwa guru telah mampu mengembangkan soal numerasi. Kendati demikian, di antara tugas yang terkumpul, ditemukan beberapa soal yang merupakan hasil salinan dari mesin pencarian. Hal ini menjadi pertimbangan untuk perbaikan metode pelatihan ke depannya.

\section{DAFTAR PUSTAKA}

Branch, R. M. (2009). Instructional design: The ADDIE approach (Vol. 722). Springer Science \& Business Media.

Cohrssen, C., \& Niklas, F. (2019). Using mathematics games in preschool settings to support the development of children's numeracy skills. International Journal of Early Years Education, 27(3), 322-339.

Darling-Hammond, L., Hyler, M. E., \& Gardner, M. (2017). Effective Teacher Professional Development.

Direktorat Jenderal Pendidikan Anak Usia Dini, Pendidikan Dasar dan Pendidikan Menengah. (2021). Data Pokok Pendidikan. https://dapo.kemdikbud.go.id/
Green, D.A. \& Riddell, W.C. (2001). Literacy, numeracy and labour market outcomes in Canada. Ottawa: Statistics Canada

Kartikasari, M., Kusmayadi, T. A., \& Usodo, B. (2016). Kreativitas guru sma dalam menyusun soal renah kognitif ditinjau dari pengalaman kerja. Prosiding Seminar Matematika Dan Pendidikan Matematika, (November), 431442.

Miller, T. Developing numeracy skills using interactive technology in a play-based learning environment. IJ STEM Ed 5, 39 (2018). https://doi.org/10.1186/s40594018-0135-2

Novita, N., Mellyzar, M., \& Herizal, H. (2021). Asesmen Nasional (AN): Pengetahuan dan Persepsi Calon Guru. JISIP (Jurnal Ilmu Sosial dan Pendidikan), 5(1).

OECD. (2019). PISA 2018 Assessment and Analytical Framework, PISA, OECD Publishing, Paris, https://doi.org/10.1787/b25efab8$\underline{\text { en }}$

Organisation for Economic Co-operation and Development, and Statistics Canada (2000). Literacy in the information age: Final report of the International Adult Literacy Study. Paris: OECD; and Ottawa: Statistics Canada. http://www1.oecd.org/publication s/e-book/8100051e.pdf

Pusat Asesmen dan Pembelajaran. (2021). AKM dan Implikasinya pada Pembelajaran. 
https://hasilun.puspendik.kemdikb ud.go.id/akm/file_akm2_202101_ $1 . \mathrm{pdf}$

Rapih, S., \& Sutaryadi. (2018). Perpektif guru sekolah dasar terhadap Higher Order Tinking Skills (HOTS): pemahaman, penerapan dan hambatan. Premiere Educandum: Jurnal Pendidikan Dasar Dan Pembelajaran. https://doi.org/10.25273/pe.v8i1.2 $\underline{560}$

Samo, D. D. (2017). Pre-Service Mathematics Teachers' Conception of Higher Order Thinking Level in Blooms'
Taxonomy. Infinity Journal. https://doi.org/10.22460/infinity.v 6i2.p121-136

Stigler, J. W., \& Hiebert, J. (2010). The Teaching Gap: Best Ideas from the World's Teachers for Improving Education in the Classroom. Http://Dx.Doi.Org/10.1080/00220 270050167215, 32(6), 867-874. https://doi.org/10.1080/00220270 050167215

Tyler, J.H., Murnane, R.J. \& Willett, J.B. (2000). Do the cognitive skills of school dropouts matter in the labor market? Journal of Human Resources, 35(4), 748-754. 